\title{
PEMANFAATAN SANSEVIERA $s p$ DALAM MENYERAP POLUSI GAS KENDARAAN BERMOTOR DI KAMPUS 2 UIN WALISONGO SEMARANG
}

\author{
Maulidatul Fathiyah, Khulmi Hasanah, Ahmad Fauzan Hidayatullah \\ UIN Walisongo Semarang Jurusan Pendidikan Biologi \\ Jl. Prof. Hamka, Ngaliyan, Semarang, Indonesia \\ E-mail : maulidatulfathiyah_1708086040@student.walisongo.ac.id
}

\begin{abstract}
Utilization of Sansevieria sp to Absorb Gas Pollution Motor Cyrcle on Campus 2 of the Walisongo State Islamic University. The increasing number of vehicles passing through campus 2 UIN Walisongo Semarang is caused by the policy of getting out of the vehicle through the parking gate at the campus gate 2. The increase in the number of vehicles causes an increase in air pollution on campus 2. To overcome this air pollution one of which can be done planting plants that can absorb pollutants. Plants that can absorb pollutants, one of which is Sanseviera sp. or tongue-in-law. This plant was chosen because it is suitable for planting in conditions of campus 2 which are arid and hot. This plant can be in a garden that is less fertile and requires less water. Sanseviera sp. can absorb pollutants memlui leaf cells. Sanseviera sp. can absorb pollutants of $46,7 \%$.
\end{abstract}

Keywords: Air Pollution; Motor Vehicles; Sanseviera sp.

\begin{abstract}
Abstrak: Pemanfaatan Sanseviera sp Dalam Menyerap Polusi Gas Kendaraan Bermotor Di Kampus 2 UIN Walisongo Semarang. Meningkatnya jumlah kendaran yang melintasi kampus 2 UIN Walisongo Semarang diakibatkan oleh kebijakan keluar kendaran melalui palang pintu parkir di gerbang kampus 2. Adanya peningkatan jumlah kendaran ini mengakibatkan meningkatnya polusi udara di kampus 2. Untuk engatasi pencemaran udara ini salah satunya dapat dilakukan penanaman tanaman yang dapat menyerap polutan.Tanaman yang dapat menyerap polutan salah satunya yaitu Sanseviera sp. atau lidah mertua.Tanaman ini dipilih karena dangat cocok ditanaman dengan kondisi kampus 2 yang gersang dan panas. Tanaman ini dapat di taman dilahan yang kurang subur dan memerlukan sedikit air. Sanseviera sp. dapat menyerap polutan memlui sel sel daunnya. Sanseviera sp. dapat menyerap polutan sebesar $46,7 \%$.
\end{abstract}

Kata Kunci: Polusi Udara; Kendaraan Bermotor; Sanseviera sp.

\section{PENDAHULUAN}

Pencemaran udara di kampus 2 UIN Walisongo mengakibatkan kualitas lingkungan di sekitarnya semakin tidak sehat. Pencemaran udara disebabkan oleh banyaknya kendaraan yang ada di kampus 2.Hal ini diperparah dengan adanya system jalan keluar yang hanya melalui kampus 2 saja. Emisi gas buang dari kendaraan dapat menyebabkan gangguan pada kesehatan. Salah satu emisi gas buang kendaraan adalah gas karbondioksida $\left(\mathrm{CO}_{2}\right)$. Selanjutnya emisi gas buang yang paling signifikan adalah dari kendaraan bermotor ke atmosfer berdasarkan massa adalah gas karbondioksida $\left(\mathrm{CO}_{2}\right)$ dan uap air $\left(\mathrm{H}_{2} \mathrm{O}\right)$ yang dihasilkan dari pembakaran bahan bakar.

Gas $\mathrm{CO}_{2}$ juga merupakan bagian yang penting dari gas rumah kaca yang memegang peranan penting dalam mengontrol suhu permukaan bumi dibandingkan dengan gas rumah kaca yang lain. Karena meskipun memiliki indeks pemanasan global yang paling kecil, tetapi konsentrasinya adalah yang paling besar setelah uap air sehingga kontribusinya terhadap perubahan suhu adalah yang paling dominan dibandingkan dengan gas rumah kaca yang lain. Gas $\mathrm{CO}_{2}$ mempunyai waktu hidup di atmosfer yang panjang yaitu sekitar puluhan ribu tahun(Daniel, 1999). 
Sumber gas $\mathrm{CO}_{2}$ tidak hanya berasal dari pembakaran bahan bakar, akan tetapi dapat berasal pembakaran biomassa,pernafasan makhluk hidup, tumpukan sampah, letusan gunung berapi, kebakaran hutan, pengeringan lahan gambut, pabrik ketika memproduksi ammonia, semen, etanol, hydrogen, besi baja bahkan dari bahan pertanian, baik dari tanahnya maupun dari tanamannya, akan tetapi tanaman tidak hanya mengeluarkan gas $\mathrm{CO}_{2}$ pada malam hari juga menyerap gas $\mathrm{CO}_{2}$ pada siang hari (Samiaji, 2011).

Solusi untuk mengurangi gas karbondioksida $\left(\mathrm{CO}_{2}\right)$ adalah dengan menanam tanaman yang mampu menyerap gas karbondioksida $\left(\mathrm{CO}_{2}\right)$ dengan baik, salah satunya adalah lidah mertua (Sansevieria sp.). Tanaman ini mudah di dapat dan dipelihara. Jenis tanamannya juga bervariasi dari umur, tinggi, ketebalan, serta kerapatan yang berbeda.

Sansevieria sp memiliki ciri-ciri berdaun tebal dan memiliki air sukulen, sehingga tahan terhadap kekeringan. Akan tetapi dalah kondisi lingkungan lembab sansevieria dapat tumbuh subur. Warna daun mulai dari hiaju tua, hiaju muda, hijau abu-abu, perak, dan warna kombinasi putih kuning atau hijau kuning. Motif alur atau garis-garis yang terdapat pada helai daun juga bervariasi, ada yang mengikuti arah serat daun, tidak beraturan, danada juga yang zig zag.(digilib.unila.ac.id). Tunas daun tumbuh dari pangkal batang atau rimpang akar di dalam tanah, akar berwarna putih dan tumbuh di pangkal batang.Batangnya tertutup oleh daun yang kaku, panjang, dan tebal sehingga dianggap sebagai batang semu (Utama, 2015).

Sansevieria $s p$ memiliki banyak kelebihan yaitu dapat hidup pada rentang waktu suhu dan cahaya yang sangat luas,resisten terhadap polutan. Menurut penelitian NASA tanaman ini dapat menyerap 107 jenis polutan di daerah yang memiliki lalu lintas yang padat dan ruangan yang penuh dengan asap rokok, serta dapat menyerap radiasi barang elektronik. Sansevieria juga memiliki daya adaptasi yang tinggi terhadap lingkungan (Megia, dkk, 2015). Tanaman ini jika di tanam di wilayah kampus akan mengurangi pencemaran udara yang ada di kampus tersebut. Penyerapan gas polutan oleh tanaman Sansevieria sp. dapat memberikan kesegaran udara yang terkena polusi gas beracun seperti karbon monoksida (CO), gas karbondioksida $\left(\mathrm{CO}_{2}\right)$, benzene, formaldehyde, dan trichloroethylene (Rosha, dkk, 2013).

Pada tahap perkembangannya, semakin tua umur Sansevieria sp. maka ukuran daun semakin lebar, sehingga luas penampang semakin besar dan kemampuan untuk menyerap polusi semakin besar. Sansevieria sp. merupakan tanaman yang mengandung bahan aktif pregnaneg likosid yang berfungsi untuk mereduksi polutan menjadi asam organic, gula dan asam amino yang tidak berbahaya bagi manusia (Haerani, dkk, 21016).Untuk itulah peneliti ingin mengetahui pemanfaatan Sansevieria $s p$ untuk mengurangi polusi gas karbondioksida di kampus 2 UIN Walisongo Semarang.

\section{BAHAN DAN CARA PENELITIAN}

Pendekatan penelitian ini adalah penelitian kualitatif yang disajikan secara deskriptif.Jenis penelitian ini merupakan penelitian library research (telaah pustaka).

\section{HASIL PENELITIAN DAN PEMBAHASAN}

Polusi atau pencemaran udara merupakan masukknya makhluk hidup, zat energi, atau komponen lain kedalam lingkungan, atau berubahnya tatanan lingkungan oleh kegiatan manusia atau proses alam sehingga kualitas udara menurun. Zat-zat pencemar udara yang paling dijumpai adalah $\mathrm{CO}, \mathrm{CO}_{2}, \mathrm{SO}_{2}, \mathrm{NO}_{2}$, dan SPM. Selain itu polusi udara dapat diakibakan oleh emulsi dari kendaran bermotor yang berbahan bakar bensin.

Adanya sistem keluar parkir yang terletak di gerbang kampus 2 UIN Walisongo membuat seluruh kendaraan bermontor harus melalui kampus 2. Meningkatnya jumlah kendaraan bermotor yang dapat menyebabkan penurunan kualitas udara. 
Polutan yang dihasilkan oleh kendaraan bermotor berupa gas karbon monoksida (CO).

Sanseviera sp. yang lebih dikenal dengan lidah mertua adalah marga tanaman hias dapat tumbuh sesuai dengan kondisi dikampus 2 yang panas dan gersang Sanseviera sp. Dapat tumbuh pada media yang tidak membutuhkan perlakuan khusus, misalnya dapat tumbuh dengan media yang kesuburannya kurang, serta tahan dengan media yang kering. Selain itu tanaman ini dapat tumbuh di luar ruangan. Sanseviera sp. dijuluki sebagai tanaman sekulen karena mengandung banyak air pada daun untuk bertahan hidup.

Penanaman Sanseviera sp. dapat ditanam di sepanjang jalan tengah antara depan gerbang kampus 2 sampai depan taman Ushuluddin sekitar 10meter dengan lebar 2 meter. Selain itu dapat pula di tanam di sela-sela taman jati, taman nyamuk, taman evolusi, depan dekanat fakultas saintek, FITK, dan depan fakultas ushuluddin. Sanseviera sp. dipilih yang berdaun lebar dan tinggi agar maksimal dalam menyerap polusi dari kendaraan bermotor.

Sanseviera sp. mempunyai kemampuan menyerap gas polutan dengan menyaring kotoran, bau atau gas polutan sehingga menjadikan udara bersih. Penyerapan gas polutan yang dihasilkan oleh pembakaran tidak sempurna dari kendaraan bermontor di kampus dapat memberikan kesegaran udara. Gas polutan beracun seperti karbon monokdida (CO), benzene, formaldehyde, dan karbon dioksida. Sanseviera sp. mampu menyerap gas polutan sebanyak $46,7 \%$.

Berdasarkan hasil kajian yang dilakukan oleh NASA (National Aeronatics and Space Administration) Amerika Serikat dan dirilis pada tahun 1999 , menunjukan bahwa Sanseviera sp. mampu menyerap lebih dari 107 unsur polutan berbahaya yang ada di udara. Menurut NASA polusi udara menyebabkan penyakit yang dikenal dengan nama sick building syndrome, yaitu suatu keadaan akut dari polusi udara terdapat dalam udara yang terjadi dalam lingkungan rumah atau perkantorandalam kondisi tertutup atau minim ventilasi. Kondisi tersebut dapat menyebabkan mata dan hidung panas seperti terbakar, tenggorokan panas dan kering, kelelahan kronis, menurunkan kemampuan konsentrasi, gemetar, mual, otot kram, kulit kasar dan kering, sakit kepala, hati berdebar,batuk, pilek dan napas tersengal(Tiara Rosa,2015).

Sanseviera sp.diyakini dapat menyerap polusi karena berdaun tebal. Sel-sel daun berfungsi menangkap karbon dioksida, karbon monoksida, dan timbal kemudian akan diolah dalam proses fotosintesis. Proses fotosontesis dapat dapat mengubah karbon dioksida yang dikeluarkan dalam sistem pernapasan menjadi oksigen yang dibutuhkan paruparu. Sanseviera sp. dapat dijadikan sebagai tumbuhan bioindikator pencemaran udara di suatu wilayah.

Negara lain yang telah menggunakan Sanseviera sp. yaitu Jepang, Korea, dan Thailand. Di jepang tanaman ini dugunakan untuk menghilangkan bau dari perabotan. Di Korea tanaman ini digunakan untuk menyerap polusi dan radiasi elektronik. Sedangkan di Thailand tanaman ini kembangkan untuk obat kanker. NASA (Badan Antariksa Amerika Serikat) menggunakan Sanseviera $s p$. untuk pembersih udara ruang angkasa

\section{KESIMPULAN DAN SARAN}

Polusi udara meningkat di kampus 2 UIN Walisongo Semarang diakibatkan oleh meningkatnya jumlah kendaraan bermotor yang melalui palang keluar parkir. Salah satu upaya yang dapat dilakukan untuk menyerap polusi adalah dengan cara melakukan penanaman tanaman Sanseviera sp. disepanjang jalan tengah antara depan taman ushuluddin sampai depan gerbang kampus 2 . Tanaman ini dapat nyerap polusi udara yaitu carbon monoksida (CO) dan polutan lainnya sebesar $46,7 \%$

\section{KEPUSTAKAAN}

1. Haerani, N., Arayani, A., Nurhasanah, N., Akhriani, N., \& Naing, I. R. 2016. Inovasi Produk Sanseviera Sebagai 
Pengharum dan Penyerap Asap.Pena: Jurnal Kreativitas Ilmiah Mahasiswa Unismuh, 3(2), 516-523.

2. Karida Tri Martuti, Nana. 2017. Peranan Tanaman Terhadap Jalan Protokol kota Semarang. Jurnal Biosantfika. ISSN 2095-19IX.

3. Megia, R. 2015. Karakteristik Morfologi dan Anatomi, serta Kandungan Klorofil Lima Kultivar Tanaman Penyerap Polusi Udara Sansevieria trifasciata.Jurnal Sumberdaya Hayati, 1(2).

4. Riani, D. 2019. Profil Pencemaran Idara Kaswasan Perkotaan Yogyakarta. Jurnal Logika: 4 (2) 96102.

5. Rosha, P. T., Fitriyana, M. N., \& Ulfa, S. F. 2016.Pemanfaatan Sansevieria Tanaman Hias Penyerap Polutan Sebagai Upaya Mengurangi
Pencemaran Udara Di Kota Semarang.Jurnal Ilmiah Mahasiswa, 3(1).

6. Syamsia., Idhan, Abubakar. 2015. Pengembangan Lidah Mertua Sebagai "Air Freshener" Ruangan dan Halaman Rumah pada Kelompok Majlis Taklim Ummul Hasanah dan AlFalaq Kecamatan Tamanalanrea Kota Makassar. Jurnal Dinamika Pengabdian. Vol 1 No. 1.

7. Samiaji, T. 2019. Gas CO2 di wilayah Indonesia.Berita Dirgantara, 12(2).

8. Utama. 2017. Klasifikasi Tanaman Lidah Mertua. https://repository.uma.ac.id (diakses pada 6 Mei 2020) 